\title{
Professional competencies in vocational rehabilitation: Results of a Delphi study
}

\author{
Tania Buys, B Occ Ther (UFS), B Occ Ther Hons (Pret), M Occ Ther (Pret) \\ Lecturer, Department of Occupational Therapy, University of Pretoria and part time Private Practitioner
}

Introduction: Opportunities for South African occupational therapists to deliver appropriate vocational rehabilitation services to workers with disabilities in the open labour market, increased within the context of current South African disability equity legislation. However research into the identification of professional competencies required to practise in this area of work had not been undertaken and this is necessary to ensure that occupational therapy curriculum content presented at South African universities are aligned with practice requirements. Research was therefore undertaken as part of the study for a master's degree, to identify these competencies. Method: A Delphi technique was employed using a panel of 35 occupational therapists representing various practice settings and meeting pre-determined expert criteria. Three rounds of questionnaires were sent to the research participants requesting them to identify knowledge, skills and values reflecting professional competencies.

Results: Following a process of data analysis, I6 professional competencies were identified as being necessary to deliver vocational rehabilitation services to workers with disabilities in the South African open labour market.

Conclusion: Based on the results of this study, recommendations are made for inclusion of professional competencies in an under- and postgraduate curriculum level. The results of this research should be further communicated to the Professional Board for Occupational Therapy, Medical Orthotics, Prosthetics and Art Therapy for consideration by the Education Committee.

Key words: Vocational rehabilitation, Delphi technique, experts, professional competencies

\section{INTRODUCTION}

The World Federation of Occupational Therapists (WFOT)' of which South Africa is a member country, recognises the right of people with disabilities to participate in work-related activities. The WFOT also acknowledges that occupational therapists have expertise in vocational rehabilitation'. Provision of vocational rehabilitation services in South Africa prior to 1994 posed many challenges to occupational therapists as the existing legal system was not inclusive of people with disabilities - one of the main client groups who benefit from vocational rehabilitation.

This discrimination changed with the enactment of the Constitution of the Republic of South Africa in 1996. The provisions of human rights, equality and non-discrimination including those of disability are explicitly stated in Chapter One of the Constitution $(1996)^{2}$. The new Constitution led to a revision of the Labour Relations Act (1995) 3 and the passing of the Employment Equity Act $(1998)^{4}$ in order to provide legislation to implement some of the rights contained in the Constitution. Although only a white paper and not enacted into legislation, the Integrated National Disability Strategy ${ }^{5}$ was developed with the intention of integrating and sustaining disability protocols in all government strategies.

The evolving human rights perspective and changing South African legal and health contexts led to renewed interest in occupational therapy in the area of vocational rehabilitation during the late 1990s. Numerous workshops were presented; vocational rehabilitation interest groups were established and the first skillsbased programme in vocational rehabilitation was implemented by the University of Pretoria ${ }^{6}$. Despite this increase in field related activity, limited research was conducted and published in vocational rehabilitation during this time. A few articles on vocational rehabilitation in occupational therapy were published in the South African Journal of Occupational Therapy that described the changing role of the occupational therapist and vocational rehabilitation services ${ }^{7-11}$.
The implementation of disability equity legislation appeared to be making an impact on service delivery in vocational rehabilitation ${ }^{12}$ and was evident in publications but no evidence was noted in publications related to academic preparation at a university level for this area of practice.

Educational and training programmes presented at the South African universities should facilitate the acquisition of knowledge, skills and values enabling students to become professionally competent for practice ${ }^{13}$. Practice expectations and educational preparation should therefore be aligned. One way of aligning practice and academia would be to seek the opinion of clinicians in identifying professional competencies ${ }^{14,15}$.

The purpose of this paper is threefold: firstly to provide a brief historical overview of vocational rehabilitation in South Africa; secondly to describe research undertaken to identify professional competencies required by occupational therapists who deliver vocational rehabilitation services to workers with disabilities in the South African open labour market and thirdly to provide suggestions for curriculum inclusion which could be considered by the Education Committee of the Professional Board for Occupational Therapy, Medical Orthotics, Prosthetics and Art Therapy and which could form the basis for further research in this area.

\section{LITERATURE REVIEW}

\section{Vocational rehabilitation in South Africa}

The development of occupational therapy vocational rehabilitation services in South Africa is not well published. The literature reflects the use of different terms when referring to the delivery of work-related services to clients. Work re-orientation ${ }^{16}$, industrial therapy ${ }^{17,18}$ and work therapy ${ }^{19}$ were used during the 1950 s and 1960s. Work preparation ${ }^{20-23}$ and work rehabilitation ${ }^{24,25}$ appear in the 1980 occupational therapy literature with vocational rehabilitation becoming a more frequently used term during the $1990 \mathrm{~s}^{7-10,26-29}$. 
Publications during the 1960s indicate that occupational therapists used sub-contract work from local businesses as well as institution based work to therapeutically intervene in the work abilities of their clients ${ }^{16,18}$. Occupational therapists shifted focus in vocational rehabilitation during the late 1970 s and 1980s and appeared to develop initiatives in an effort to improve the economic independence of their clients as employment in the open labour market (competitive employment) was not achievable ${ }^{12}$. South African occupational therapists attempted to solve this by becoming involved in preparing their clients for home industries to supplement their income ${ }^{30-34}$. In 1983 Priscilla Stevenson, an occupational therapist, established Access College which offered business training for people with disabilities thereby facilitating placement in the open labour market ${ }^{35}$. This college was unique in South Africa and the first attempt to improve the skills of people with disabilities in an environment which catered specifically for their needs. In a further attempt to improve the economic independence of people with disabilities, MODE (Medunsa Organisation for Disabled Entrepreneurs) was established in the early 1990s by Vivienne Zwennis, also an occupational therapist ${ }^{36}$. The programme provided business training to people with disabilities and their families. MODE further assisted their clients in obtaining business loans and to establish viable small businesses at community level.

Despite the above initiatives, anecdotal information suggests that occupational therapists were increasingly frustrated with both vocational rehabilitation service delivery as well as successful placement of people with disabilities in the open labour market. In an attempt to address this aspect, the then Transvaal Provincial Government established a Vocational Rehabilitation Work Group in 1989 with the purpose of improving service delivery within provincial health services. A flurry of activity within vocational rehabilitation was noted with the inception of the group, and many workshops presented during the early $1990 \mathrm{~s}^{12}$. A position paper on "The Role of the Occupational Therapist in Vocational Rehabilitation" was compiled by the group members in collaboration with a variety of occupational therapy clinicians and submitted to the professional organisation for publication in 1992 but this was never published ${ }^{\prime 2}$. In addition the group also facilitated the establishment of the South African Society of Vocational Rehabilitation (SASVR) in I 993 which attempted to include various vocational rehabilitation stakeholders including representation from business to promote and enhance networking, promote vocational rehabilitation and improve the employment outcomes of people with disabilities. It was difficult for the SASVR to achieve its vision in a society undergoing substantial political, social and economic changes and it disbanded in 1996.

Randall ${ }^{31}$ stated as early as 1988 that occupational therapists should continue with efforts to promote employment opportunities and fair labour practices for their clients, and despite the professional activity in vocational rehabilitation; open labour market placement for people with disabilities remained difficult to achieve. Although a number of factors could be attributed to this according to the Integrated National Disability Strategy ${ }^{5}$, discriminatory and ineffective South African labour legislation was seen as contributing to high levels of unemployment amongst people with disabilities ${ }^{5}$.

Following South Africa's first democratic elections and the subsequent acceptance of a democratic government, existing South African labour laws were reviewed with new laws enacted in order to embrace the principles of the Constitution ${ }^{2}$. The Labour Relations Act specifically the Code of Good Practice Dismissal (Schedule 8) was one of the first laws to address the issue of managing employee incapacity on the grounds of ill-health and injury ${ }^{3}$ and laid the foundation for the assessment of employees' ability to perform their work as well the implementation of adaptations to sustain employment. The Employment Equity Act ${ }^{4}$ promulgated in 1998 was the first act to specifically address disability in the work place by defining disability and providing the framework for reasonable accommodations to both retain people with disabilities at work (existing employees) as well as to facilitate entry into the open labour market by job seekers with disabilities. The legal platform was therefore established for the provision of vocational rehabilitation service delivery by occupational therapists but professional competencies required for service delivery were not yet determined.

\section{Professional competency}

Professional competence is not an easy concept to define ${ }^{13,37,38}$ with no generally accepted description. Grossman ${ }^{38}$ states that competence includes a person's knowledge, skills and clinical judgement as well as practice environmental demands. For the purposes of this research, professional competencies refer to the sum total of capacities which an occupational therapist possesses and which are believed relevant to the field of vocational rehabilitation practice ${ }^{12}$. Professional competency includes knowledge, skills and professional values.

\section{METHODOLOGY}

\section{Design}

In the absence of relevant published information specifically on professional competencies, various consensus methods are suggested to seek the opinion of experts ${ }^{39-41}$. In order to obtain consensus and facilitate input from experienced occupational therapists over a wide geographical area in an equitable manner, the Delphi technique was used. Characteristics of this technique include making use of a panel of experts or informed individuals who complete sequential rounds of written questionnaires anonymously. Controlled feedback is provided to panel members between rounds in order to keep them informed of the collective response of the panel. The number of rounds varies according to time, research aims and other factors, from two to five rounds until consensus of opinion is achieved on the research topic ${ }^{41,42}$.

\section{Ethical clearance}

Ethical clearance was obtained from the Ethics Committee of the Faculty of Health Sciences of the University of Pretoria. All research participants completed informed consent forms, a copy of which was returned to them for record keeping purposes.

\section{The expert panel}

The use of experts as members of the panel is a key characteristic of the Delphi technique ${ }^{4 !}$. Experts are described as knowledgeable and experienced and the panel should reflect diversity of experience, diversity of expertise and diversity of interests ${ }^{43}$. Literature differs on the number of panel members with 10 to $50^{44}$ and more than $100^{45}$ being used thus there is little agreement concerning the expert panel size ${ }^{41}$. In two South African occupational therapy studies, the expert panel size was $20^{46}$ and 45 members ${ }^{47}$. A panel size of 35 expert occupational therapists was decided by the researcher as this number was used by Stokes ${ }^{48}$ in a related study.

Two-hundred-and-fifty-six occupational therapists working in the field of vocational rehabilitation were identified. Potential panel members were compiled from lists of private practitioners from the Occupational Therapy Association of South Africa (OTASA) membership list and its affiliated organisations. Potential panel members from occupational therapists in the insurance industry, postgraduate diploma students in vocational rehabilitation and attendees of continuing professional development workshops were also identified. Contact was made with all eight South African universities that trained occupational therapists, to identify lecturers whose key responsibilities were teaching vocational rehabilitation. The contents of the South African Journal of Occupational Therapy and insurance-related publications were reviewed to identify occupational therapists who had published on vocational rehabilitation topics after 1995 following the implementation of disability equity legislation as these authors would be viewed as experts ${ }^{41}$. Use was made of a snowball sampling technique in order to identify as many occupational practitioners as possible.

Non-probability sampling was applied to the total population to enable the selection of a 35-member panel representing a variety of practice settings, experience and expertise using predetermined 
criteria thereby limiting selection bias ${ }^{48}$. First quota sampling was conducted in order to ensure maximum variation. Ten different groupings of occupational therapists were identified from the list of 256 occupational therapists. These groups comprised occupational therapists working in private practice, in hospitals, and schools, in insurance, in training and in supported employment settings. The remaining four groups of occupational therapists were those who had published, were actively involved in the implementation of related disability equity law, held postgraduate qualifications and who were teaching in the area of vocational rehabilitation at a South African university. Purposive sampling was then applied and 35 potential panel members were selected on the basis of percentage representation in the group of 256 occupational therapists.

All 35 potential panel members were telephonically contacted by the researcher to explain the research purpose and methodology. Emphasis was placed on how lengthy the process was anticipated to be in order to obtain assurance that they would have adequate available time to participate in the process ${ }^{41}$. Permission was obtained to send potential panel members informed consent forms. Three potential panel members were not able to participate, which resulted in the selection of three other panel members applying the same selection criteria. On receipt of all forms, the research commenced.

\section{Pilot study}

Once the expert panel had been identified, a pilot study was conducted to obtain feedback and suggestions on the informed consent form, first round Delphi questionnaire, definitions of terminology and biographical forms in terms of layout, clarity and completion time frames. The purpose of the pilot study was to eliminate potential research problems $\mathrm{s}^{40-42,48,49}$. A convenience sample was selected from the initial group of 256 occupational therapists (excluding the identified panel members) to reflect diversity of practice settings and ability to give constructive feedback to the researcher. After informed consent had been obtained, written and verbal feedback was collected from the five pilot study participants during individual interviews. Appropriate improvements were made to all the research documents.

\section{Delphi rounds}

Three Delphi technique rounds were conducted with sequential questionnaires based on data from the preceeding one. Each questionnaire was accompanied by an information letter, which included definitions of terminology, researcher contact details and (where appropriate) feedback/results from the previous questionnaire. Quasi anonymity was assured with tracking numbers allocated to all Delphi questionnaires ${ }^{41}$.

The first round Delphi technique questionnaire was qualitative in nature and consisted of open-ended questions requesting panel members to identify knowledge, skills and values in each vocational rehabilitation phase. These phases, described by the International Labour Office ${ }^{50}$, were regarded as a generally accepted framework for South African occupational therapists working in vocational rehabilitation ${ }^{12}$. The vocational rehabilitation phases used by occupational therapists for the purposes of this research were: (i) evaluation/assessment of workers, (ii) vocational guidance - seen as an interpretation and planning phase in terms of achieving work and/or return-to-work, (iii) vocational preparation including both treatment/intervention such as work hardening, stress management and other interventions which would improve a client's ability to work, as well as training - both formal and informal skills training, (iv) placement, and (v) followup. Panel members were also requested to identify knowledge, skills and values that did not fit into any of the identified vocational rehabilitation phases in order to generate further ideas regarding vocational rehabilitation.

Data from the first round Delphi questionnaire resulted in 896 knowledge, skill and value items in the vocational rehabilitation phases. Content analysis was applied and data were manually coded by the researcher into categories and items ${ }^{41}$. The process of data analysis resulted in II categories with 405 items. In addition to the vocational rehabilitation phases, four new categories of information emerged from this process. These were legislative (related to the employment of people with disabilities), employment settings (placement possibilities), general management and embedded knowledge, skills and values (not specifically related to vocational rehabilitation). Themes were not identified at this stage to ensure that each item could be considered in order to achieve consensus ${ }^{41}$.

The second round Delphi questionnaire was developed using the categories and items generated from the first questionnaire. Panel members were asked how strongly they agreed or disagreed, on a five point Likert Scale ${ }^{41,51}$, with each item. For each item provision was made for qualitative comments.

Both quantitative and qualitative data analyses were applied to the round two Delphi questionnaire. Data from this questionnaire were statistically analysed together with a statistician from the University of Pretoria. The mean and standard deviation were calculated $^{41,51}$. Items for possible inclusion for the third round Delphi questionnaire were selected, provided that the mean minus one standard deviation was greater than 3,5 (out of 5), ensuring agreement between panel members ${ }^{39,52-55}$. This list of items was organised in rank order of their means. Content analysis was applied. The ranked items were systematically analysed by the researcher in order to logically combine items of similar meaning in order to collapse the total number of items. Qualitative comments provided by panel members were considered during this process.

The process of content analysis resulted in the II categories being collapsed into three categories and 212 items in the third round Delphi questionnaire. The new categories which emerged were knowledge, skills and values as $86 \%$ of the panel members were of the opinion that these were essential to all phases of vocational rehabilitation. This was a significant change in the Delphi questionnaires. Data were statistically analysed with a consensus rate set at $80 \%{ }^{39,56,57}$.

\section{Trustworthiness of data}

The various strategies of Lincoln and Guba's Model of Trustworthiness $^{58}$ were applied to ensure research rigour. Prolonged engagement was obtained through the lengthy and iterative nature of the Delphi technique. Researcher credibility was established and all research processes and documentation were subjected to peer examination. A feedback and planning interview on the completion of each Delphi questionnaire were held with the supervisor. Both a confirmability and dependability audits were conducted by a research consultant not directly involved in the research process. All raw data, process notes and working documents were used for this process.

\section{RESEARCH RESULTS}

\section{Questionnaire response rate}

There are no clear guidelines in terms of Delphi response rates but in order to maintain research rigour, a $70 \%$ response rate was set by the researcher in order to maintain research rigour ${ }^{59}$. This was achieved by telephonically following up panel members at regular intervals and providing feedback on the results of the questionnaires. Of the 35 panel members, 29 (83\%) returned the first round Delphi questionnaire. All 29 (I00\%) members returned the second round Delphi questionnaire and $28(97 \%)$ of the 29 panel members returned the third round Delphi questionnaire.

\section{Biographical profile of expert panel}

Biographical information requested during the first Delphi round indicated that nine $(31 \%)$ of the panel members were involved in full-time private practice; five (17\%) were employed in the insurance sector; three $(10 \%)$ in full-time academic posts with representation in all the other strata. Nineteen panel members had more than 10 years vocational rehabilitation experience. Panel members obtained their occupational therapy degrees from six 
of the eight South African universities, with 12 (42\%) graduating from the University of Pretoria. Twenty six (90\%) panel members had postgraduate qualifications, with $18(51 \%)$ of the panel having obtained their Post Graduate Diploma in Vocational Rehabilitation at the University of Pretoria.

\section{Knowledge, skills and values}

Using an $80 \%$ consensus level, agreement was obtained amongst the participants on knowledge, skills and professional values required for service delivery. Consensus was achieved on eleven knowledge themes with 64 items; I 3 skill themes with 93 items and 47 value items (no themes logically emerged in the skill category). They include, but are not limited, to the following knowledge and skill themes and value items ${ }^{12}$ :

* Knowledge of various health related conditions; vocational rehabilitation (general aspects); employment settings; disability related legislation; various team players and their roles; evaluation; vocational guidance; intervention strategies; training; placement and follow-up.

* Skills in general vocational rehabilitation aspects; communication; legislation - application of skills within legislative and scope of practice parameters; team work; evaluation; job analysis; vocational guidance; intervention; training; placement; followup; general aspects (but not specific to vocational rehabilitation only) and management.

* Values include ethical behaviour, objectivity, insight, integrity, consistency, confidence, respect, commitment, dedication, adaptability, empathy, determination, professionalism, using client centred approach, quality assurance and perseverance.

\section{Development of professional competency statements}

The work of Coursey et al, ${ }^{60}$ was considered during the formulation of professional competency statements required by occupational therapists who deliver vocational rehabilitation services to workers in the open labour market. Knowledge, skills and values items identified during the research process were combined into professional competences. Sixteen professional competencies emerged:

\section{Professional competencies (see Table on page 52)}

I. Has knowledge of a variety of health related conditions. Occupational therapists should understand the condition, its impact on the client's ability to work and related prognostic indicators. An understanding of inappropriate illness behaviour is necessary.

2. Understands and implements various vocational rehabilitation services. Services include injury prevention, health risk management, disability management, disability equity consulting and case management.

3. Understands the requirements of various employment settings in order to facilitate employment/placement for people with disabilities. These employment settings include the open labour market, sheltered-, protected- and supported employment. Occupational therapists should be able to use various work classification systems including those of the physical demands classification.

4. Understands aspects of labour, disability equity, health and safety, skills development and related legislation appropriate to vocational rehabilitation. These include the Labour Relations Act and its Code of Good Practice: Dismissal; the Employment Equity Act and its accompanying Code of Good Practice and Technical Assistance Guideline on the employment of people with disabilities; the Skills Development Act as well as the Occupational Health and Safety Act. Occupational therapists should understand how insured and government funded benefits are structured for people who become ill, injured or disabled - both whilst performing their work duties as well as off-duty. These include workman's compensation, the Department of Labour's Unemployment Insurance Fund, various social grants including disability grants administered by the South African Social Security Agency, as well as group insured benefits. Knowledge of building regulations for people with disabilities is essential. Occupational therapists should be able to deliver vocational rehabilitation services within the legal context given the occupational therapy scope of practice.

5. Communicates appropriately using various media in diverse settings including business. Compiles timeous written reports and communicates effectively on an individual and group level using appropriate presentation media.

6. Collaborates with various team members and role players during the provision of vocational rehabilitation services. These role players include human resource managers, employers, work supervisors, safety representatives and union members.

7. Evaluates work related abilities and skills of clients requiring vocational rehabilitation services. Conducts comprehensive functional capacity evaluations in various settings, for various purposes using a variety of standardised and non-standardised tests. Formulates appropriate conclusions and recommendations.

8. Conducts job analysis through work place visits, job description review and interview of relevant stakeholders. Matches the requirements of the work with the abilities of the client and recommends reasonable accommodations where appropriate.

9. Understands and applies the vocational guidance process. Facilitates client's insight into their abilities and work requirements thereby enabling participation in decision making and planning.

10. Understands various treatment/intervention strategies and plans, implements, grades, evaluates and manages work readiness/work preparation programmes that facilitate return to work or employment for clients. Strategies include on-site treatment using job trials and transitional work programmes, work hardening, work conditioning, work simulation, back hygiene and ergonomic principles, life skills, stress management, prevocational skills and job-seeking skills training.

I I. Facilitates training/skills acquisition and re-skilling in order to facilitate placement in the open labour market. Knows of informal and formal education and training programmes for people with disabilities and refers clients appropriately. Sensitises trainers to disability when required.

12. Facilitates placement/employment or return to work for clients who have disabilities/injuries or who are ill. Understands potential employment barriers and how to bridge them. Knows of job finding and job search resources and networks appropriately. Sets up support systems during the placement process.

I3. Implements follow-up processes to determine success of vocational rehabilitation services. Understands the purpose of follow-up and conducts follow-up with both client and employer. Closes the case.

I4. Possesses management skills. Exhibits time management, business planning, project management, financial management, human resource, and administration skills.

15. Reflects professional behaviours and attributes which are considered necessary to deliver vocational rehabilitation services. Displays clinical reasoning and interpersonal skills. Is able to think proactively and laterally; works creatively and innovatively with confidence; is a dedicated and adaptable practitioner who is determined to overcome barriers.

16. Reflects values consistent with the "Guidelines on ethical conduct, rules, regulations and policy documents" as reflected in the 15 guideline booklets published by the Health Professional Council of South Africa ${ }^{61}$. 


\begin{tabular}{|c|c|c|}
\hline $\begin{array}{l}\text { Professional } \\
\text { competency }\end{array}$ & Undergraduate curriculum & Postgraduate curriculum \\
\hline I & $\begin{array}{l}\text { Understands the theoretical aspects of various health } \\
\text { related conditions; the impact thereof on the performance } \\
\text { of work as well as related prognostic indicators. }\end{array}$ & $\begin{array}{l}\text { Has a deeper understanding of a large variety of health related } \\
\text { conditions including inappropriate illness behaviour coupled with } \\
\text { appropriate field-work (clinical) experience. }\end{array}$ \\
\hline 2 & $\begin{array}{l}\text { Understands various vocational rehabilitation services, and } \\
\text { applies the vocational rehabilitation process within the } \\
\text { hospital, school and community contexts. }\end{array}$ & $\begin{array}{l}\text { Conducts the identified services within a variety of contexts } \\
\text { such as the business and industry-type environments. }\end{array}$ \\
\hline 3 & $\begin{array}{l}\text { Has knowledge of selected work classification systems, } \\
\text { the requirements of the open labour market as well as } \\
\text { knowledge of employment settings other than the open } \\
\text { labour market. }\end{array}$ & $\begin{array}{l}\text { Has knowledge of the employment process as well as applying } \\
\text { this process to his/her clients. Understands the role of various } \\
\text { role players in the employment context. }\end{array}$ \\
\hline 4 & $\begin{array}{l}\text { Understands the purpose of the related Disability Equity } \\
\text { laws, as well as a general understanding of the laws in order } \\
\text { to refer a client for assistance when appropriate. }\end{array}$ & $\begin{array}{l}\text { Applies and integrates these laws to vocational rehabilitation } \\
\text { service delivery i.e. has working knowledge of these laws. } \\
\text { Advising clients on their legal rights is not a requirement of this } \\
\text { competency. }\end{array}$ \\
\hline 5 & $\begin{array}{l}\text { Compiles reports addressed to appropriate role players } \\
\text { with guidance. Visual presentation skills should be } \\
\text { developed as part of undergraduate training. }\end{array}$ & $\begin{array}{l}\text { Communicates with various industry-related role players } \\
\text { regarding vocational rehabilitation services. }\end{array}$ \\
\hline 6 & $\begin{array}{l}\text { Develops in various contexts in which a student conducts } \\
\text { field-work. }\end{array}$ & $\begin{array}{l}\text { This is linked to the previous professional competency and is } \\
\text { developed with experience. }\end{array}$ \\
\hline 7 & $\begin{array}{l}\text { Conducts work related assessment, with guidance, in work, } \\
\text { school and community settings. Requires guidance in the } \\
\text { interpretation of the results and formulating a conclusion } \\
\text { and recommendations. }\end{array}$ & $\begin{array}{l}\text { Conducts work related assessments in a variety of } \\
\text { contexts as well as for various purposes such as insurance } \\
\text { benefits, compensation purposes as well as return-to-work } \\
\text { determination. }\end{array}$ \\
\hline 8 & Conducts job analysis with guidance. & $\begin{array}{l}\text { Matches client's abilities to the requirements of the work using } \\
\text { a variety of job analysis methods. Makes recommendations } \\
\text { regarding reasonable accommodations and implements these. Is } \\
\text { able to assess a broad range of occupations. }\end{array}$ \\
\hline 9 & Understands the vocational guidance process. & Applies the vocational rehabilitation process. \\
\hline 10 & $\begin{array}{l}\text { Understands various intervention strategies and can } \\
\text { implement these for individual and groups of clients in } \\
\text { schools, hospitals and community settings. Has skills } \\
\text { in the following programmes: life skills training, stress } \\
\text { management, pre-vocational skills training, facilitation } \\
\text { of motivation and action, treatment of client factors and } \\
\text { performance skills as well as rehabilitation aspects. }\end{array}$ & $\begin{array}{l}\text { Implements treatment and prevention strategies in the work } \\
\text { place for individual and groups of clients. Demonstrates skills } \\
\text { in the following types of programmes: work hardening, work } \\
\text { conditioning, work simulation, ergonomics, counselling and job } \\
\text { seeking skills training. }\end{array}$ \\
\hline 11 & $\begin{array}{l}\text { Has knowledge of various skill training programmes and } \\
\text { refers clients appropriately. }\end{array}$ & $\begin{array}{l}\text { Implements training programmes for clients to facilitate return- } \\
\text { to-work and/or employment. }\end{array}$ \\
\hline 12 & Has knowledge of the placement process. & $\begin{array}{l}\text { Implements placement procedures in order to facilitate return- } \\
\text { to-work and/or employment. }\end{array}$ \\
\hline 13 & Has knowledge of the follow-up process. & Implements follow-up procedures. \\
\hline 14 & Manages time and organizes work load. & $\begin{array}{l}\text { Has knowledge and skills in the following: business planning, } \\
\text { costing, managing projects, managing staff and clients, } \\
\text { administration skills and marketing. }\end{array}$ \\
\hline 15 & Professional behaviours are developed and nurtured. & Professional behaviours are further developed. \\
\hline 16 & Ethical behaviours are developed and nurtured. & $\begin{array}{l}\text { Ethical behaviours are further developed. Accountability for } \\
\text { ethical behaviour is developed. }\end{array}$ \\
\hline
\end{tabular}

\section{DISCUSSION}

Although there are no universally accepted guidelines for the application of the Delphi technique and researchers remain critical of the limitations thereof ${ }^{41,62-64}$, it was an appropriate technique for this study. It facilitated equal say from the panel members which would not have taken place with other consensus techniques.

All possible actions were taken by the researcher to overcome the shortcomings of the Delphi during the research process. Careful attention was paid to the selection of panel members to reflect diversity of experience and commitment to the field of vocational rehabilitation. Various authors ${ }^{41,62-64}$ report that there is no consensus in literature regarding the optimum number of panel members. $\mathrm{Hsu}^{63}$ argues that a small panel might not be considered representative of the population whilst a poor response rate could be associated with a larger panel. Sandrey and Bulger $^{62}$ conclude, following their literature review, that the panel should at least include 10 members with no significant changes in results in panels larger than 25-30 members. The panel size selected by the researcher appeared to bridge these limitations and was manageable. A higher response rate than $70 \%$ (which as the highest rate suggested in literature) was achieved by implementing various strategies including maintaining constant contact with the panel through reminders, content of letters, frequent emails and feedback ${ }^{41,62}$. This assured a very low attrition rate and contributed towards panel/sample motivation ${ }^{41}$ both necessary for research rigour. 
Given the above discussion, providing the demographics of the panel, the results of this research process appear to provide a valid opinion $^{41}$ of occupational therapists in South Africa.

The results of this research further appear consistent with published international studies ${ }^{65-67}$. Aspects which did not appear to be identified by the research participants as clearly as in the international studies include injury prevention ${ }^{65-67}$, health promotion ${ }^{65}$, evidence based practice ${ }^{66}$ as well as injury and illness management and rehabilitation ${ }^{67}$.

\section{RECOMMENDATIONS}

Based on the research process recommendations are made for inclusion in the occupational therapy curriculum on both an underand postgraduate level (Table I on page 53).

\section{CONCLUSION}

This research process appears to be the first in the area of South African vocational rehabilitation in terms of identifying professional competencies required to deliver vocational rehabilitation services. This contributes to the body of authentic South African research in the area of vocational rehabilitation as there does not appear to have been previously documented related research, or research published after this research was completed. Further research is currently being conducted by the author to determine whether these professional competencies are reflected in South African undergraduate occupational therapy curricula. During this process it would also be essential to determine to what extent the identified professional competencies are reflected in the Health Professions Council of South Africa's Professional Board for Occupational Therapy, Medical Orthotics, Prosthetics and Art Therapy - Minimum Standards of Training for Occupational Therapists - as all universities are required to comply with these standards.

Ongoing and further research in vocational rehabilitation and in particular in the education and training of occupational therapists in this area of practice is of paramount importance. Many occupational therapists enter this area of practice and anecdotal evidence appears to suggest that other health professionals are as well. We need to as an occupational therapy profession to ensure that we provide competent, professional, contextually relevant vocational rehabilitation services to clients which enables them to fulfil their roles as independent citizens in a democratic South Africa free from disability discrimination.

\section{ACKNOWLEDGEMENTS}

The author expresses sincere appreciation to the expert Delphi panel members as well as the pilot study participants without whom this research would not have been possible. Their enthusiasm and passion for this research was very tangible. Without the immeasurable support and constant encouragement from Marlie Aronstam, Anneliese Kruger, Prof Margot Graham and Prof Daleen Casteleijn this research would not have been completed. And then to Hester van Biljon for the inspiration for this article. Your enthusiasm and support in the area of vocational rehabilitation and in particular in this area of research, is the reason for the existence of the article.

\section{REFERENCES}

I. World Federation of Occupational Therapists (WFOT). Position Statement: Vocational Rehabilitation [Online]. <http://www.wfot. org/resour $>(20 / 10 / 2014)$.

2. Constitution of the Republic of South Africa. Republic of South Africa Government Gazette, 1996; Notice 108 of 1996. Vol 378: Nol7678.

3. Labour Relations Act. Republic of South Africa Government Gazette, 1995; Notice 66 of 1995. Vol 366: No 1686I.

4. Employment Equity Act. Republic of South Africa Government Gazette, 1998; Notice 55 of 1998. Vol 400: No 19370.

5. Office of the Deputy President TM Mbeki. White Paper on an Integrated National Disability Strategy: 1997.

6. Buys T. Professional competencies in occupational therapy work practice: What are they and how should these be developed? Work 2007; 29(I): 3-4.

7. Joubert $\mathrm{R}$. The $17^{\text {th }}$ Vona du Toit Memorial Lecture. Where from? What now? Where to? South African Journal of Occupational Therapy, 1997; 27(I): 5-15.

8. Strasheim P, Buys T. Vocational rehabilitation under new constitutional, labour and equity legislation in a human rights culture: Future directions for South African occupational therapists. South African Journal of Occupational Therapy, 1996; 26(2): 14-28.

9. van Biljon HM. Occupational therapy, the new Labour Relations Act and vocational rehabilitation evaluation: a case study. South African Journal of Occupational Therapy, 1997; 27(I): 23-30.

10. Shipham E. Bolts and Nuts: The competitive edge. South African Journal of Occupational Therapy, 1995; 25(2): 4- 12.

II. Buys TL, van Biljon $\mathrm{H}$. Occupational therapy in occupational health and safety: dealing with disability in the work place. Occupational Health South Africa, 1998; Sept/Oct: 30-33.

12. Buys TL. Professional competencies required by occupational therapists delivering work practice services to workers with disabilities in the South African open labour market. 2006; MOccTher; University of Pretoria.

13. Ellis R, editor. Professional competence and quality assurance in the caring professions. London: Chapham and Hall, 1988.

14. Wittman PP. The disparity between educational preparation and the expectations of practice. The American Journal of Occupational Therapy, 1990; 44(I2): II30-II3I.

15. McCluskey A. Collaborative curriculum development: clinicians' views on the neurology content of a new occupational therapy course. Australian Journal of Occupational Therapy, 2000; 47(I): I- I0.

16. Fordyce DF. Work assessment in the psychiatric field. South African lournal of Occupational Therapy, 1967; I (18): 4-7.

17. Harrisberg J. Industrial therapy in cerebral palsy. South African Journal of Occupational Therapy, I 963; I (I I): 25-26.

18. Binet B, Grisdale M, Gearing B. Industry comes to hospital. South African Journal of Occupational Therapy, 1963: I(I I): 27-29.

19. Borowitz AH, Kretzmer N. Work therapy with epileptic psychotic patients. South African Journal of Occupational Therapy, 1959; October: 3-7.

20. Shipham E. The functioning of a Medical Fitness for Work Unit. Rehabilitation South Africa, 1984; March: 8-14.

21. du Toit N, van Heerden R. Die gebruik van 'n opleidingsentrum na voltooing van ' $n$ werksvoorbereidingprogram, vir psigiatriese pasiënte. South African Journal of Occupational Therapy, 1987; I7(I): 36-38.

22. Williams E. Die voorbereiding van gestremde persone vir die inskakeling in die arbeidsmark deur Arbeidsterapie Medies Geskiktheid vir Werk-afdeling: HF Verwoerd Hospitaal. Rehabilitation in South Africa, 1989; June: 30-33.

23. Pretorius $C$. Activity and work programmes. The role of the occupational therapist in the treatment of persons with epilepsy. South African Journal of Occupational Therapy, 198I; II(I): 6-8.

24. Beukes S. Werkrehabilitasie - benutting van gemeenskapsbronne. South African Journal of Occupational Therapy, 1983; I3(I): 24-26.

25. Sutherland A. Work placement of schizophrenic patients: a pilot study of opportunities and attitudes. South African Journal of Occupational Therapy, 1984; 14(2): 26-29.

26. Buys $T$, Wessels $E$. The need for support groups after vocational rehabilitation. South African Journal of Occupational Therapy, 1991; 2I(2): 34-37.

27. van Biljon $H$, Naik $P$. The vocational rehabilitation unit at Hillbrow Hospital: then and now. South African Journal of Occupational Therapy, 1991; 21 (I): 30-37.

28. van Biljon $\mathrm{H}$. The relevance of the Valpar in the South African context. South African Journal of Occupational Therapy, 1994; 24(2): 16-19.

29. Jansen P. Vocational rehabilitation following brain damage: alternative approaches and functional models of retraining. South African Journal of Occupational Therapy, 1994; 24 (2): 20-24.

30. McLaren P. Basic shoe repairing as a home industry for the African paraplegic. South African Journal of Occupational Therapy, 1977; 7(I): I0-II.

31. Randall LE. Home industries for the urban disabled: the role of the occupational therapist. South African Journal of Occupational 
Therapy, 1988; 18 (2): 26-31.

32. Redeker A. Home industry in the spinal unit at Conradie Hospital. South African Journal of Occupational Therapy, I 977; 7(I): 8-9.

33. Cawood J. Vegetable gardening as a home industry for patients confined to wheelchairs. South African Journal of Occupational Therapy, I 98I; II(I): 3-5.

34. Friis IL. A home industry requires small business training. South African Journal of Occupational Therapy, 1983; I3(I): 27-28.

35. Stevenson PA. Access College - doorway to independence. South African Journal of Occupational Therapy, 1984; 14(2): 5I-57.

36. van der Merwe A. An able MODE of thinking!! Rehabilitation in South Africa, 1995; June: 4-5.

37. Youngstrom MJ. Evolving competence in the practitioner role. The American Journal of Occupational Therapy, 1998; 52(9): 716-720.

38. Grossman J. Continuing competence in the health professions. The American Journal of Occupational Therapy, 1998 Oct; 52(9): 709715.

39. Barker K, Burns M. Using consensus techniques to produce clinical guidelines for patients treated with the Ilizarov Fixator. Physiotherapy, 200I; 87(6): 289-300.

40. Hasson F, Keeney S, McKenna H. Research guidelines for the Delphi survey technique. Journal Advanced Nursing, 2000; 32(4): 10081015.

4I. Keeney S, Hasson F, McKenna H. The Delphi Technique in Nursing and Health Research, Oxford: Wiley-Blackwell, $201 \mathrm{I}$.

42. Couper MR. The Delphi technique: characteristics and sequence model. Advances in Nursing Science, 1984; 7(I): 72-77.

43. Bijl R. Delphi in a future scenario study on mental health and mental health care. Futures, 1992; April: 232-250.

44. Linestone HA, Turoff M. The Delphi Method. Techniques and applications. London: Addison-Wesley Publishing Company, 1975.

45. Everett $A$. Piercing the veil of the future. A review of the Delphi method of research. Professional Nurse, 1993; 9(3): 181-185.

46. Byrne LJ. The current and future role of occupational therapists in the South African group life insurance industry. South African Journal of Occupational Therapy, 2003; 33(2): 2-10.

47. Shipham E, van Velze C. Core characteristics of a newly qualified occupational therapist. South African Journal of Occupational Therapy, 1993; 23(2): 16-25.

48. Stokes F. Using the Delphi Technique in planning a research project on the occupational therapist's role in enabling people to make vocational choices following illness or injury. British Journal of Occupational Therapy, 1997; 60(6); 263-267.

49. Skulmoski GJ, Hartman FT, Krahn J. The Delphi method for graduate research. Journal of Information Technology Education, 2007, $6 ;|-2|$.

50. International Labour Office. Basic principles of vocational rehabilitation of the disabled, Geneva: ILO, 1995.

51. Greatorex J, Dexter T. An accessible analytical approach for investigating what happens between the rounds of a Delphi study. Journal of Advanced Nursing, 2000; 32(4): 1016-1024.

52. Mcknight J, Edwards N, Pickard L, Underwood J, Voorberg N, Woodcox V. The Delphi approach to strategic planning. Nursing Management, 1991; 22: 55-57.

53. Duffield C. The Delphi technique: a comparison of results obtained using two expert panels. International Journal of Nursing Studies, 1993; 30(3): 227-237.

54. Ingram D. Opinions of Physical Therapy education program directors on essential functions. Physical Therapy, 1997; 77(I): 37-45.

55. Jairath N, Weinstein J. The Delphi Methodology (Part One): A Useful Administrative Approach. Canadian Journal of Nursing Administration, 1994; Sep- Oct: 29-42.

56. Deane KHO, Eli-Hill C, Dekker K, Davies P, Clarke CE. A survey of current occupational therapy practice for Parkinson's disease in the United Kingdom. British Journal of Occupational Therapy, 2003; 66(5): 193-200.

57. Green S. Travelling via Delphi: A new route for the accreditation of fieldwork educators. British Journal of Occupational Therapy, 1996; 59(II): 506-5I0.

58. Krefting $L$. Rigor in qualitative research: The assessment of trustworthiness. The American Journal of Occupational Therapy, 1991; 45(3): $214-222$.

59. Sumsion T. The Delphi technique: an adaptive research tool. British lournal of Occupational Therapy, 1998; 6I (4): 153-I56.

60. Coursey RD, Curtis L, Marsh DT, Campbell J, Harding C, Spaniol L, Lucksted A, McKenna J, Kelley M, Paulson R, Zahniser J. Competencies for direct service staff members who work with adults with severe mental illness in outpatient public mental health/managed care systems. Psychiatric Rehabilitation Journal, 2000; 23(4): 370377.

61. Health Professions Council of South Africa. Ethical rules, regulations and policy documents. < http://www.hpcsa.co.za/Conduct/Ethics $>$ (I0/04/2015).

62. Sandrey MA, Bulger SM. The Delphi method: An approach for facilitating evidence based practice in athletic training. Atheletic Training Journal, 2008; 3(4): I35-I 42. www.natacj.org (I6/04/2015).

63. Hsu CC. The Delphi technique: making sense of consesnus. Practical Assessment, Research \& Evaluation, 2007; I 2(10): I -8. < http:// pareonline.net/getvn.asp? $v=12 \& n=10>(16 / 04 / 2015)$.

64. Yousuf MI. Using experts' opinions through Delphi technique. Practical Assessment, Research \& Evaluation, 2007; I2(4): I-8. <http:// pareonline.net/getvn.asp? $v=12 \& n=4>(16 / 04 / 2015)$.

65. Adam K, Gibson E, Lyle A, Strong J. Development of roles for occupational therapists and physiotherapists in work-related practice: An Australian perspective. Work, 2010; 36(3): 263-272.

66. Adam K, Strong J, Gibson E, Lyle E, Chiphase L. Preparing novice occupational therapists and physiotherapists for work-related practice: What attributes are required? Journal of Health and Environment, 2012; 28(2): 189-202.

67. Adam K, Peters S, Chipchase L. Knowledge, skills and professional; behaviours required by occupational therapist and physiotherapist beginning practitioners in work-related practice: A systematic review. Australian Occupational Therapy Journal, 20 I 3; 60(): 76-84.

Corresponding Author

\section{Tania Buys}

tania.buys@up.ac.za

Post Net Suite 205

Private Bag X1007

Lyttelton 0140

Pretoria 